Check for updates

The BMJ

Cite this as: $B M J 2021 ; 375: \mathrm{n} 2739$

http://dx.doi.org/10.1136/bmj.n2739

Published: 10 November 2021

\title{
Covid-19: BMA asks doctors to submit evidence on UK's pandemic response
}

Gareth lacobucci

The BMA has called for evidence to inform its "lessons learnt” review into the UK's handling of the covid-19 pandemic, ahead of a statutory inquiry led by the UK government next year.

The association is contacting members, medical royal colleges, and leading think tanks to understand how the government's handling of the pandemic has affected doctors' lives, the NHS, patient care, and public health. It aims to identify lessons that will enable action both in the immediate future, as the NHS continues to deal with pressures from covid-19, and in the longer term to ensure that the health service and wider system are better prepared for future pandemics.

The BMA outlined five key areas for its review: protecting healthcare workers from covid-19, the impact of the pandemic on the medical profession, delivering healthcare during the pandemic, the public health response to the pandemic, and the impact of the pandemic on population health.

Last month a report from the House of Commons Health and Social Care Select Committee condemned serious errors in the UK government's early response to the pandemic, ${ }^{12}$ including delays to locking down, inadequate procurement of personal protective equipment (PPE), and delayed implementation of a system to test, trace, and isolate.

The BMA launched its review in July, arguing that next year was too long to wait to learn lessons from the response. It says that the evidence it gathers will directly inform the association's submissions to the UK public inquiry.

\section{Redeployed}

Chaand Nagpaul, BMA council chair, said that hearing first hand from members was "absolutely central to the BMA's review ... Their experiences have been truly sobering-from doctors who worked on the front lines, exposed to a deadly virus with inadequate or non-existent PPE, to witnessing illness and death at levels they were never trained to handle."

He added, "Their professional lives were turned upside down, with many redeployed from their normal jobs to support critical covid care as well as working excessive hours. Healthcare workers in hospital were left to provide pastoral care for patients at the end of life, without visitors, family, or friends. These distressing moments made worse by witnessing their colleagues becoming ill and the tragedy of several hundred healthcare workers losing their own lives from the virus. Doctors have been left with physical exhaustion and emotional trauma with no sense of respite.
"It's these voices that must be at the forefront of helping us understand what happened during covid-19, so that the nation is properly prepared and does not sleepwalk into a future tragedy of this scale again. They must be heard if we are to tackle the gargantuan pressures ahead and ensure the government can properly support healthcare workers-those who went above and beyond to keep our country safe."

1 Science and Technology Committee, Health and Social Care Committee. Coronavirus: lessons learned to date. Oct 2021. https://committees. parliament.uk/committee/81/health-and-social-care-committee/news/157991/coronavirus-lessons-learned-to-date-report-published

2 O'Dowd A. Covid-19: Government's handling of pandemic had "big mistakes," MPs say. BMJ 2021;375:n2487. doi: 10.1136/bmj.n2487 pmid: 34642173

This article is made freely available for use in accordance with BMJ's website terms and conditions for the duration of the covid-19 pandemic or until otherwise determined by BMJ. You may use, download and print the article for any lawful, non-commercial purpose (including text and data mining) provided that all copyright notices and trade marks are retained. 